\title{
Fluoxetine Hcl Induced Intrauterine Foetal Growth Retardation And Skeletal Malformation In Pregnant Mice
}

\author{
Ali,M.O. ;Sharf-El Deen, U.A.. ; El Menshawy,O.M. and Bakry,S.A.
}

\author{
Zoology Dept. Fac. Sci., Al-Azhar Univ., Nasr city, Cairo, Egypt.
}

\begin{abstract}
Fluoxetine is antidepressant drug which widely known as Prozac ${ }^{\circledR}$, is a fluorinated methyl phenoxy derivative of phenylpropylamine. Fluoxetine is a bicyclic antidepressant that differs structurally and pharmacologically from other currently available antidepressant agents. 80 pregnant mice were administrated oral doses of Fluoxetine $(0.052,0.104 \& 0.208 \mathrm{mg} / \mathrm{mouse}$ /day) From $6^{\text {th }}$ up to both $15^{\text {th }}$ and $19^{\text {th }}$ days of gestation.

The pregnant mice treated with Fluoxetine $\mathrm{HCl}$ showed states of instability, nervousness, twitching of head, agitation, hazy movement and marked reduction in food intake as well as reduction in the body weight. The results of uteri examination of pregnant mice groups on both $15^{\text {th }}$ and $19^{\text {th }}$ days of gestation showed remarkable reduction in their size, dismorphology, length and number of implantation sites as well as large reduction in the number of still live embryos.

Increase in the number of dead and resorbed mouse embryos was dose dependant. Also, the results showed reduction in both body weight and crown rump of mouse embryos. The treated mouse foetuses showed several malformations as diminution in size, exenocephalia and skeletal malformations.
\end{abstract}

Key words: Fluoxetine, Mice, Teratogenicity, Malformations, Dead and resorbed embryos.

\section{Introduction}

The problem of psychotropic drug teratogenicity has apparent in the very recent years and directed a great attention of the authors toward this problem. Over 10.000 cases of congenital anomalies in infants in Germany attributed to Thalidomide (one individual of Tranquilizers) have been recorded between 1960 and 1962. Sommi et al. (1987) and ElNahass, 1988 ) showed that when rats, administrated doses up to nine times of Fluoxetine of those recommended for humans did not affect fertility but caused reduced maternal food intake and weight gain and a slight reduction in neonatal survival. No teratogenic effects have been observed in vivo. Fluoxetine and its metabolite Norfluoxetine have been shown to cross the placenta in the rats and are at highest levels in foetal brain and thymus (Pohland et al., 1989). The same results were reported by many investigators (Cooper, 1988; Hoyt,1989; Byrd \& Markham ,1994 and Vorhees et al., 1994). Isenberg (1990) revealed that, Fluoxetine and its metabolite (Norfluoxetine) secreted in human breast milk. Limited data indicate that Fluoxetine and Norfluoxetine concentrations are (20-30\%) concurrent maternal plasma drug concentration. Fluoxetine was not teratogenic in rat and rabbits at doses equivalent to (9 and 11) fold the maximum daily human therapeutic dose respectively. A slight decrease in maternal survival was seen in rats exposed to (5 and 9) times the maximum human therapeutic dose; this may have been due to maternal toxicity (Goldstein, 1990). The exposure of mouse embryos in whole embryo culture to Sertarline (SSRI) at concentration, which produced no evidence of general embryotoxicity, caused by craniofacial malformations consistent with direct action of 5HT (5-hydroxytryptamine) uptake sites (Shuey et al., 1992).

Both Fluoxetine and Sertarline are inhibit the proliferation of cardiac mesenchyme endocardium. These effects were most pronounced when exposure began at embryo day $9^{\text {th }}$. These results suggested that 
5-HT may play a role in cardiac morphogenesis during endocardial cushion formation (Sadler et al., 1993).

Mary et al. (1993) revealed that there have been no reported cases of Prozac toxicity in neonate. The mother was prescribed $20 \mathrm{mg}$ of Prozac each day during most of her pregnancy by her Psychiatrist for sever depression. She had a good prenatal care and a normal labor. (Pastuszak et al., 1993) suggested that the use of Fluoxetine during the first trimester is not associated with major malformations. Also, women exposed to Fluoxetine and tricyclic antidepressant (TCA) tend to report higher rates of miscarriage. Stanford and Patton, (1993) stated that Fluoxetine HCl (Prozac) might cause adverse vascular effects such as hematoma in rats exposed in utero. When pregnant rats administrated 5.62 $\mathrm{mg} / \mathrm{kg}$ Fluoxetine $\mathrm{HCl}$ by oral gaving beginning on the $7^{\text {th }}$ day of gestation and ending on the birthday. Higher frequency of skin hematoma was found in exposed pups. Fluoxetine did not produce significant neurodevelopmental effects in the offspring of Sprague - Dawley rats given oral doses up to $12 \mathrm{mg} / \mathrm{kg}$ on $7^{\text {th }}$ day up to $20^{\text {th }}$ day of gestation. The highest dose resulted in reduced litter size and increased neonatal mortality, but was also toxic to the dam, as evidenced by maternal weight loss during gestation (Vorhees et al., 1994).

On the other hand, Koren et al. (1994) revealed that the use of antidepressant Fluoxetine during embryogenesis is not associated with an increased risk of major malformation and further studies are needed to clarify the teratogenic effect of this drug which affects a central nervous system neurotransmitter. Also, (Goldberg and Nissim, 1994) showed that, there is no controlled studies have ever been done in pregnant women to truly prove their safety, it is appears that most, but not all, current psychotropic drugs appears fairly safe for use in pregnancy. In a study by David et al. (1997) they found that maternal Fluoxetine exposure dose not represents a significant risk of teratogenicity in rats, rabbits and mice.

Recently, many investigatores revealed the embryotoxcity and side effects of the anti-depressant drugs during the different developmental periods on the experimental animals and human being ( Moiseiwitsch, 2000; Sharama, 2001; Fung \& Ferrill, 2001; Mitchell et al., 2001). They reported that the Antidepressant drugs, especially tricyclics have been widely used in the treatment of chronic pain, but not in acute pain. Because of numerous undesirable side effects, the selective serotonin reuptake inhibitors (SSRIs), with their favorable side effect profile, are preferred nowadays. The former one, reported that the children of patients who have received selective serotonergic re-uptake inhibitors (such as Prozac and Zoloft) or the less selective tricyclic anti-depressant drugs (such as Elavil) would be at a higher risk for developmental dental defects such as anodontia and hypodontia. Who reported that the 5-HT induced intercellular $\mathrm{Ca}(2+)$ which inhibit the $\mathrm{Ca}$ metabolism. So, this study was planned to study the effect of prozac (the most widely used psychatropic drug in Egypt) on foetal growth and skeletal formation in mice at different times of gestation. And to follow up any abnormalities may be done

\section{Materials and Methods}

The present study was carried out using mature male and female mice (Swiss westeber) of an average body weight (25-30 g.). They were apparently normal, healthy animals and obtained from Helwan Laboratory Farms of Egyptian Organization for Vaccine and Biological preparations. This work was conducted on 80 pregnant mice, divided into 2 main groups (belonging to stage $15^{\text {th }} \& 19^{\text {th }}$ days of gestation) each consists of 4 subgroups of pregnant mice, groups $1 \& 5$ consist of control gravid mice belonging to stage $15^{\text {th }}$ $\& 19^{\text {th }}$ days of gestation respectively. The drug was administered by oral intubation route dissolved in distilled water. Mature males were caged at the afternoon for overnight with virgin females in a ratio of one male/two females/cage. At the next morning the presence of the vaginal plug was considered or designated as the first day of the pregnancy according to (Sanyal \& Eric, 1979, Barlow et al., 1980 and Ali et 
al., 1989). Where they remained undisturbed until the morning of the $6^{\text {th }}$ day of gestation. The pregnant females were transferred from the mating cages and rehoused in groups; each group consists of 10 animals as the following GI\&GV designated as control groups for $15^{\text {th }}$ and $19^{\text {th }}$ days of gestation rspectively, while GII, GIII and GIV were treated with Fluoxetine $\mathrm{HCl}$ doses $(0.052,0.104 \& 0.208 \mathrm{mg} / \mathrm{mouse}$ /day) From $6^{\text {th }}$ up to both $15^{\text {th }}$ days of gestation and GVI, GVII and GVIII were treated with Fluoxetine $\mathrm{HCl}$ doses $(0.052$, $0.104 \& 0.208 \mathrm{mg} / \mathrm{mouse} /$ day) from $6^{\text {th }}$ up to $19^{\text {th }}$ day of gestation. The pregnant mice were killed by the cervical dislocation after $12 \mathrm{hrs}$ from the last dose, the gravid uteri were dissected out, and foetuses were removed, weighted and examined for the live, dead and resorbed foetus numbers according to Cook \& Farweather (1968) and Barlow et al. (1980). A numbers of embryos from each pregnant mouse were placed in Bouins solution for a maximum of 2 days before assessment of external malformations and measuring of crown-rump length. Then embryos were photographed with standard scale, in accordance to Kaplan \& Grabowski (1967). All animals in the pervious 8 groups were weighted and behaviorally observed daily to estimate the changes in the behavior and body weight during the experiment. Some foetuses from each group were stained with Alizarin red S accordance to the methods of (McColl et al., 1963 and Globus \& Gibson, 1968) in order to study the skeletal malformations.

\section{Results}

Among the experimental groups rash or urticaria and facial oedema appeared in some individuals. Also, diarrhea, dizziness and convulsions were observed in most individuals of the experimental groups. More events were appeared in the all treated groups with nervousness, twitching of head, agitation and hizzy movement.Food intake was also observed among the treated groups, which is gradually decreased by increasing of the dose and days of gestation, food intake was completely reduced in most groups before sacrificing.
The effects of Fluoxetine $\mathrm{HCl}$ doses on the body weights of the pregnant mice were shown in table (1). The data indicated a decrease in the body weight of the experimental groups when compared with the corresponding control. These reductions in the body weights were statistically highly significant $(\mathrm{P} \leq 0.01)$ and dose dependant.

The isolated uteri of control pregnant mice at $15^{\text {th }}$ day of gestation $(\mathrm{GI})$ one uterus shown in Plate 2 (A) clarifies the equal distribution of the embryos in both uterine horns, without any signs of resorption or other abnormalities. While Plate 2 (B,C \& D) showing the unequal distribution, a symmetrical distribution early and late resorbed embryos in the uterus isolated from treated group GII, GIII and GIV, which reflect the signs of dismorphology. On the other side, the isolated uteri at the $19^{\text {th }}$ day of gestation from GV, which designated as a control group represented in Plate 2 ( E ), manifested with the distribution of normal embryos in both uterine horns, without any signs of abnormalities. The examination of isolated uteri obtained from GVI, GVII and GVIII revealed that the most common characters are the reduction in the number of embryos, dismorphology of the uterine horns, remarkable decrease in the number of embryos and shortness of whole uterus as well as early resorption of embryos in both horns in comparison with control uterus as represented in Plate $2(\mathrm{~F}, \mathrm{G} \& \mathrm{H})$.

Fluoxetine $\mathrm{HCl}$ with various doses administrated orally to the pregnant mice from $6^{\text {th }}$ day up to both $15^{\text {th }}$ and $19^{\text {th }}$ days of gestation induced reduction in the number of implantation sites, number of still lives mouse embryos as well as embryo body weight and crown rump of the mouse embryos. While induces increase in the number of both dead and resorbed embryos as well as several fetuses malformations which manifested in diminution of size , anencephaly, subcutaneous hecatomb , edematous cites as well as protrusion of both eyes and brain. These teratogenicity items was dose dependant when compared with the corresponding control belonging to each stage as shown in table (1) and plates $1(\mathrm{~A}-\mathrm{D})$. 
Fluoxetine Hcl Induced Intrauterine Foetal Growth........

Table (1): Effect of Fluoxetine Hcl doses on the pregnant mice and their offspring at both stages of gestation.

\begin{tabular}{|c|c|c|c|c|c|c|c|c|}
\hline \multirow{2}{*}{ Groups } & \multicolumn{4}{|c|}{ Stage $15^{\text {th }}$ day } & \multicolumn{4}{|c|}{ Stage $19^{\text {th }}$ day } \\
\hline & $\begin{array}{c}\text { GI } \\
\text { control }\end{array}$ & $\begin{array}{c}\text { GII } \\
0.052 \mathrm{mg}\end{array}$ & $\begin{array}{l}\text { GIII } \\
0.104 \mathrm{mg}\end{array}$ & $\begin{array}{l}\text { GIV } \\
\quad 0.208 \mathrm{mg}\end{array}$ & $\begin{array}{c}\text { GV } \\
\text { control }\end{array}$ & $\begin{array}{c}\text { GVI } \\
0.052 \mathrm{mg}\end{array}$ & $\begin{array}{c}\text { GVII } \\
0.104 \mathrm{mg}\end{array}$ & $\begin{array}{l}\text { GVIII } \\
0.208 \mathrm{mg}\end{array}$ \\
\hline $\begin{array}{l}\text { Mother body } \\
\text { weight }\end{array}$ & $34.71 \pm 1.50$ & $26.02^{* \star} \pm 1.04$ & $25.70^{\star \star} \pm 0.70$ & $25.18^{* *} \pm 0.90$ & $37.91 \pm 0.70$ & $29.88^{* *} \pm 0.70$ & $26.60^{* *} \pm 1.00$ & $26.69^{* \star} \pm 0.70$ \\
\hline $\begin{array}{l}\text { Implantation } \\
\text { sites }\end{array}$ & $9.56 \pm 0.30$ & $8.70^{*} \pm 0.52$ & $8.28^{* *} \pm 0.50$ & $7.71^{* *} \pm 0.73$ & $9.71 \pm 0.68$ & $8.57^{*} \pm 0.79$ & $7.47^{* *} \pm 0.46$ & $4.99^{* *} \pm 0.41$ \\
\hline $\begin{array}{l}\text { Still live } \\
\text { embryos }\end{array}$ & $9.28 \pm 0.67$ & $5.57^{* *} \pm 0.66$ & $4.85^{* *} \pm 0.72$ & $3.71^{* *} \pm 0.53$ & $9.57 \pm 0.42$ & $6.57^{*} \pm 0.60$ & $5.0^{* *} \pm 0.43$ & $2.0^{* *} \pm 0.11$ \\
\hline $\begin{array}{l}\text { Dead } \\
\text { embryos }\end{array}$ & $0.28 \pm 0.05$ & $1.71^{* *} \pm 0.57$ & $1.85^{* *}+0.40$ & $2.00^{* *}+0.65$ & $0.14+0.02$ & $1.28^{* *}+0.28$ & $1.42^{* *}+0.42$ & $1.71^{* *}+0.41$ \\
\hline $\begin{array}{l}\text { Resorbed } \\
\text { embryos }\end{array}$ & 0.00 & $1.42 \pm 0.10$ & $1.57 \pm 0.18$ & $2.00 \pm 0.11$ & 0.00 & $0.72 \pm 0.01$ & $1.00 \pm 0.01$ & $1.28 \pm 0.03$ \\
\hline Crown rump & $1.93 \pm 0.04$ & $1.58^{* *} \pm 0.14$ & $1.08^{* *} \pm 0.05$ & $0.8^{* *} \pm 0.04$ & $2.64 \pm 0.03$ & $2.1^{* *} \pm 0.03$ & $1.73^{* *} \pm 0.04$ & $1.36^{* *} \pm 0.03$ \\
\hline $\begin{array}{c}\text { Embryo } \\
\text { body weight }\end{array}$ & $1.24 \pm 0.03$ & $0.89^{* *} \pm 0.04$ & $0.43^{\star *} \pm 0.03$ & $0.24^{\star \star} \pm 0.03$ & $1.76+0.03$ & $1.30^{\star \star} \pm 0.06$ & $0.98^{\star *} \pm 0.02$ & $0.91^{* *} \pm 0.04$ \\
\hline
\end{tabular}

Data in table expresses as : Mean \pm standard error

$*$ = significant

$* *=$ highly significant 
Table (2): Teratogenic effect of Fluoxetine HCl (Prozac) doses on the skeletal system of the mouse embryo at both stages.

\begin{tabular}{|c|c|c|c|c|c|c|c|}
\hline & \multirow{2}{*}{ Groups } & \multicolumn{3}{|c|}{ Stage $15^{\text {th }}$ Days } & \multicolumn{3}{|c|}{ Stage $19^{\text {th }}$ Days } \\
\hline & & $\begin{array}{c}\text { Gll } \\
0.052 \mathrm{mg}\end{array}$ & $\begin{array}{c}\text { GIII } \\
0.104 \mathrm{mg}\end{array}$ & $\begin{array}{c}\text { GIV } \\
0.208 \mathrm{mg}\end{array}$ & $\begin{array}{c}\text { GVI } \\
0.052 \mathrm{mg}\end{array}$ & $\begin{array}{c}\text { GVII } \\
0.104 \mathrm{mg}\end{array}$ & $\begin{array}{c}\text { GVIII } \\
0.208 \mathrm{mg}\end{array}$ \\
\hline \multirow{2}{*}{$\begin{array}{l}\overline{\bar{z}} \\
\bar{v}\end{array}$} & $\begin{array}{l}\text { Incomplete } \\
\text { ossification }\end{array}$ & 61.11 & 71.43 & 82.22 & 55.56 & 64.44 & 75.56 \\
\hline & $\begin{array}{l}\text { complete } \\
\text { ossification }\end{array}$ & 38.89 & 28.57 & 17.78 & 44.44 & 35.56 & 24.44 \\
\hline \multirow{4}{*}{$\stackrel{\mathscr{0}}{\frac{0}{x}}$} & $\begin{array}{l}\text { Irregular } \\
\text { shape }\end{array}$ & 36.51 & 40.53 & 25.38 & 20.28 & 22.67 & 49.12 \\
\hline & Missed & 25.29 & 28.16 & 42.85 & 31.64 & 36.91 & 31.87 \\
\hline & $\begin{array}{l}\text { Incomplete } \\
\text { ossification }\end{array}$ & 22.20 & 18.21 & 21.39 & 29.18 & 24.18 & 11.24 \\
\hline & $\begin{array}{c}\text { Complete } \\
\text { ossification }\end{array}$ & 16.00 & 13.10 & 10.38 & 18.90 & 16.24 & 7.77 \\
\hline \multirow{3}{*}{ 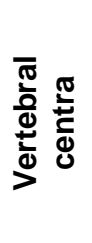 } & Missed & 46.33 & 68.57 & 76.83 & 36.75 & 41.67 & 66.16 \\
\hline & Scoliosis & 14.66 & 19.74 & 13.17 & 35.14 & 38.16 & 21.24 \\
\hline & Normal & 39.01 & 11.69 & 10.00 & 28.11 & 20.17 & 12.60 \\
\hline \multirow{2}{*}{ 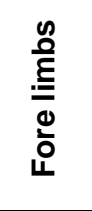 } & $\begin{array}{l}\text { Incomplete } \\
\text { ossification }\end{array}$ & 71.15 & 78.41 & 92.24 & 58.33 & 61.75 & 72.64 \\
\hline & $\begin{array}{l}\text { complete } \\
\text { ossification }\end{array}$ & 28.85 & 21.59 & 7.76 & 41.67 & 38.25 & 27.36 \\
\hline \multirow{2}{*}{ 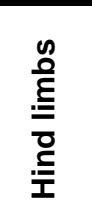 } & $\begin{array}{l}\text { Incomplete } \\
\text { ossification }\end{array}$ & 57.14 & 81.14 & 95.16 & 63.97 & 68.14 & 77.89 \\
\hline & $\begin{array}{c}\text { Complete } \\
\text { ossification }\end{array}$ & 42.86 & 18.86 & 4.84 & 36.03 & 31.86 & 22.11 \\
\hline
\end{tabular}

The data represented as percentage $(\%)$. 

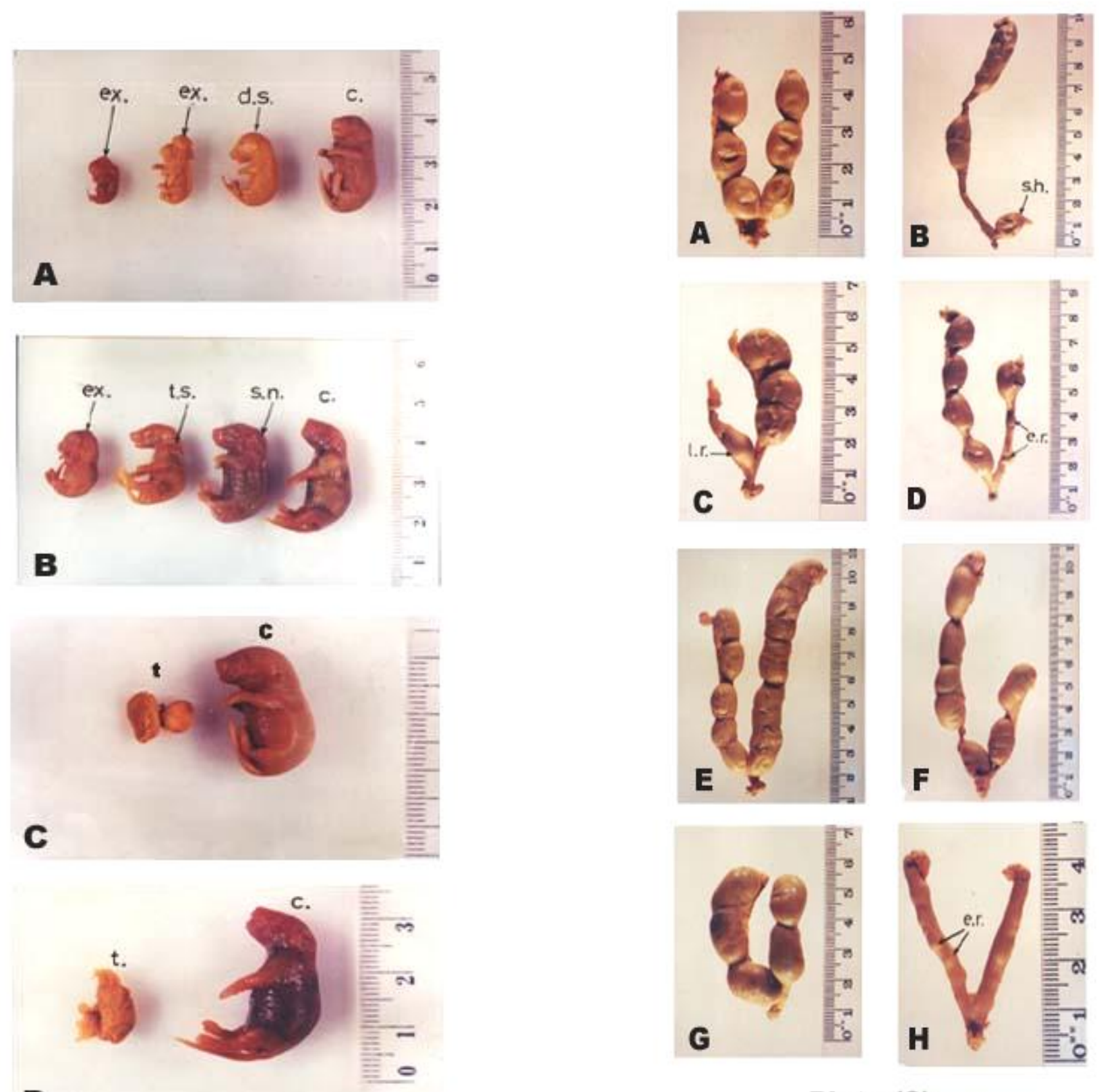

Plate (2)

\section{Plate (1)}

Plate (1): A\&B- Photomicrograph of control mouse embryo (C) on $15^{\text {th }}$ and $19^{\text {th }}$ day of gestation respectively. While other embryos in (A-D) from treated mice showing (d.s.) diminution of size, (ex.) exencephally, (s.n.) shortness of neck as well as (t.s.) thin skin.

Plate (2): A \& E - Photomicrograph of control uterus on both $15^{\text {th }}$ and $19^{\text {th }}$ day of gestation respectively, showing normal distribution of embryos. B,C \& D -Uteri from treated mice from $6^{\text {th }}$ up to $15^{\text {th }}$ day of gestation showing (s.h.) shortness of horn, both early and late resorbed embryos (l.r. \& e.r.) .While (F,G \& H) Uteri from treated mice from $6^{\text {th }}$ up to $19^{\text {th }}$ day of gestation showing shortness of horn and early resorbed (e.r.). 

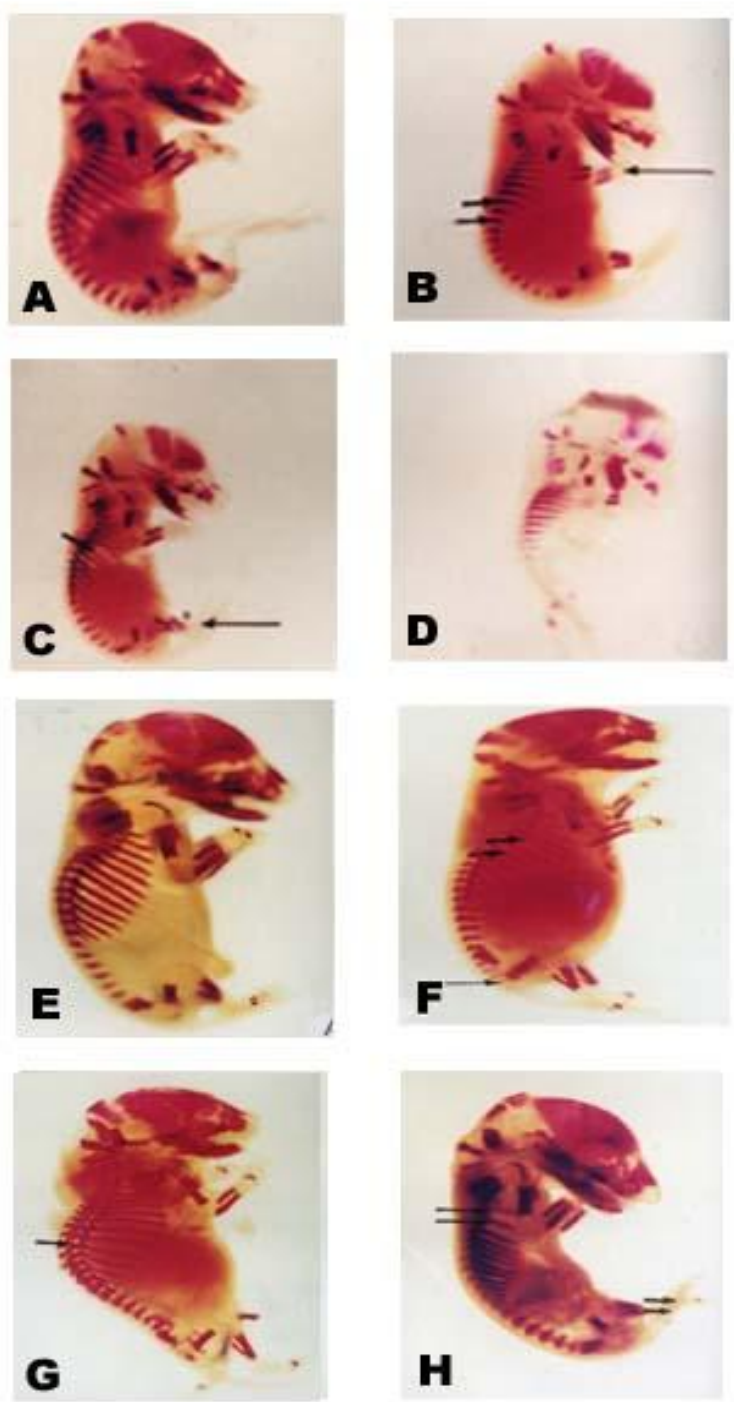

Plate (3)
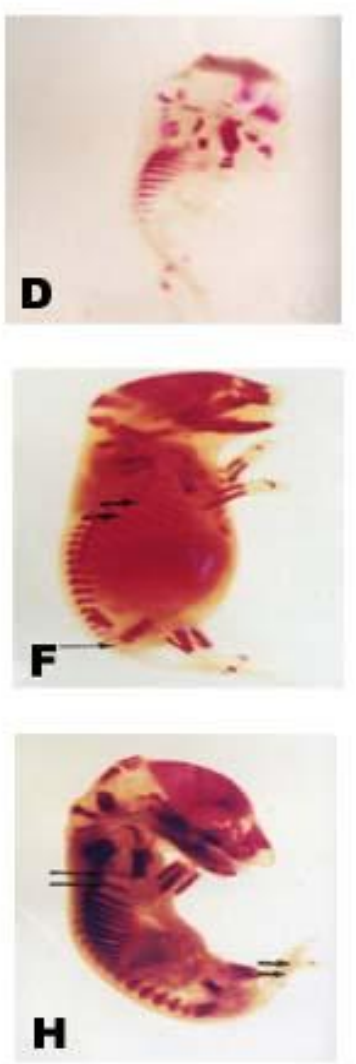
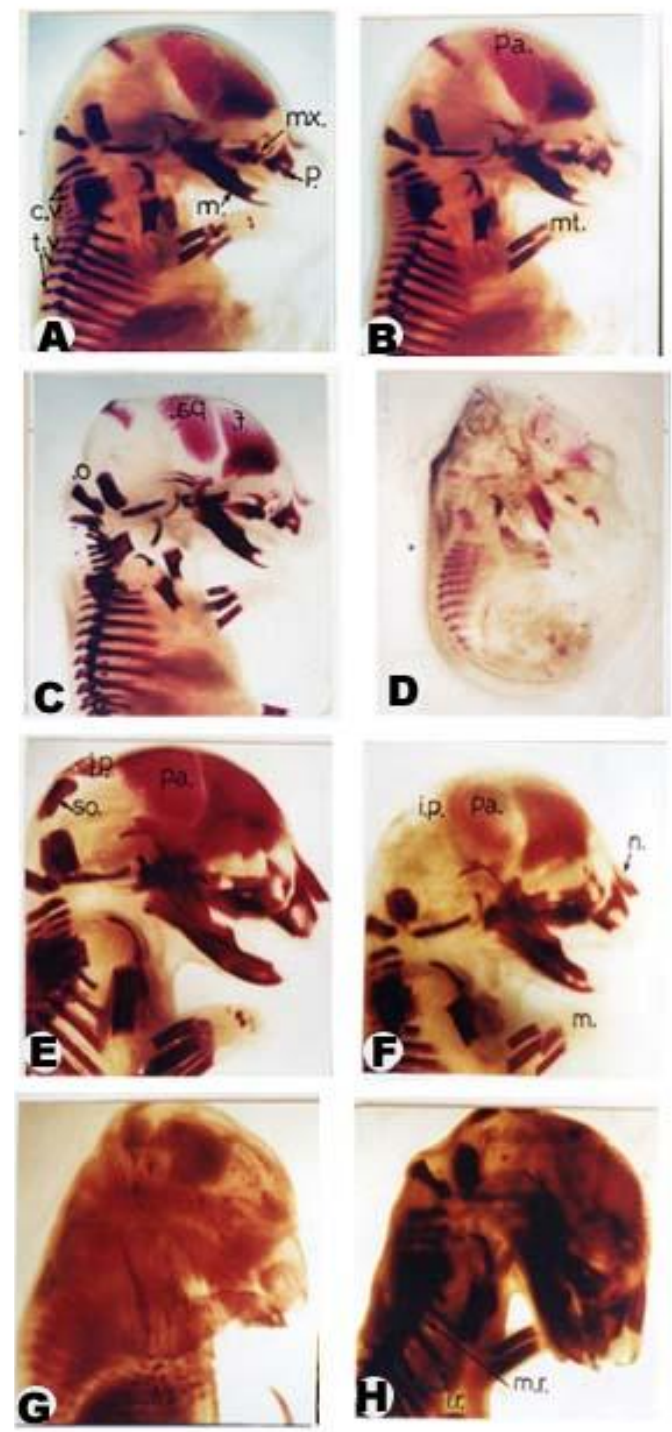

Plate (4)

Plate (3): A \& E - Photomicrograph of control mouse skeletal on both $15^{\text {th }}$ and $19^{\text {th }}$ day of gestation respectively, showing normal ossification of embryos. B,C \& D -treated mouse embryos at $15^{\text {th }}$ day showing missed ribs (short arrows) and absence of carpals and tarsus bones (long arrows). While, F,G \& H- Treated mouse embryos at $19^{\text {th }}$ day showing missed ribs (short arrows) in $F \& H$, scoliosis in $G$ and absence of tarsus bones in $\mathbf{H}$.

Plate (4): A \& E - Photomicrograph of control mouse skeletal on both $15^{\text {th }}$ and $19^{\text {th }}$ day of gestation respectively, showing normal ossification of embryo skull. B,C,D, F,G \& $\mathrm{H}$ - treated mouse embryos at both $15^{\text {th }} \& 19^{\text {th }}$ days showing poor ossification of some skull bones. (c.v. ), (t.v.) cervical and thoracic vertebrae, (m.n.) mandibles, (p.) premaxilla (m.x.) maxilla ,(pa.) parital ,(mt.) metacarpals, (f.) frontal , (sq.) squamosal and (o.) occipital region . 

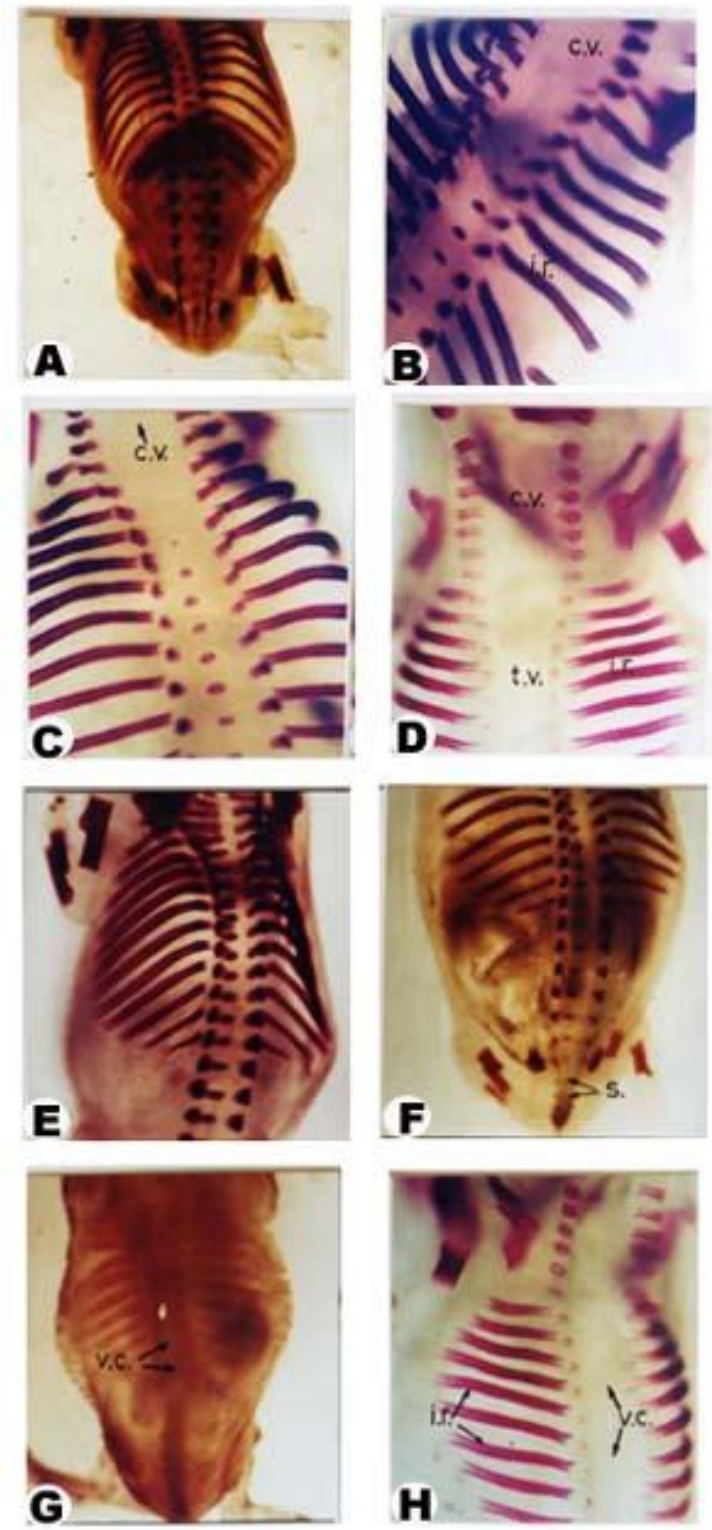

Plate (5)
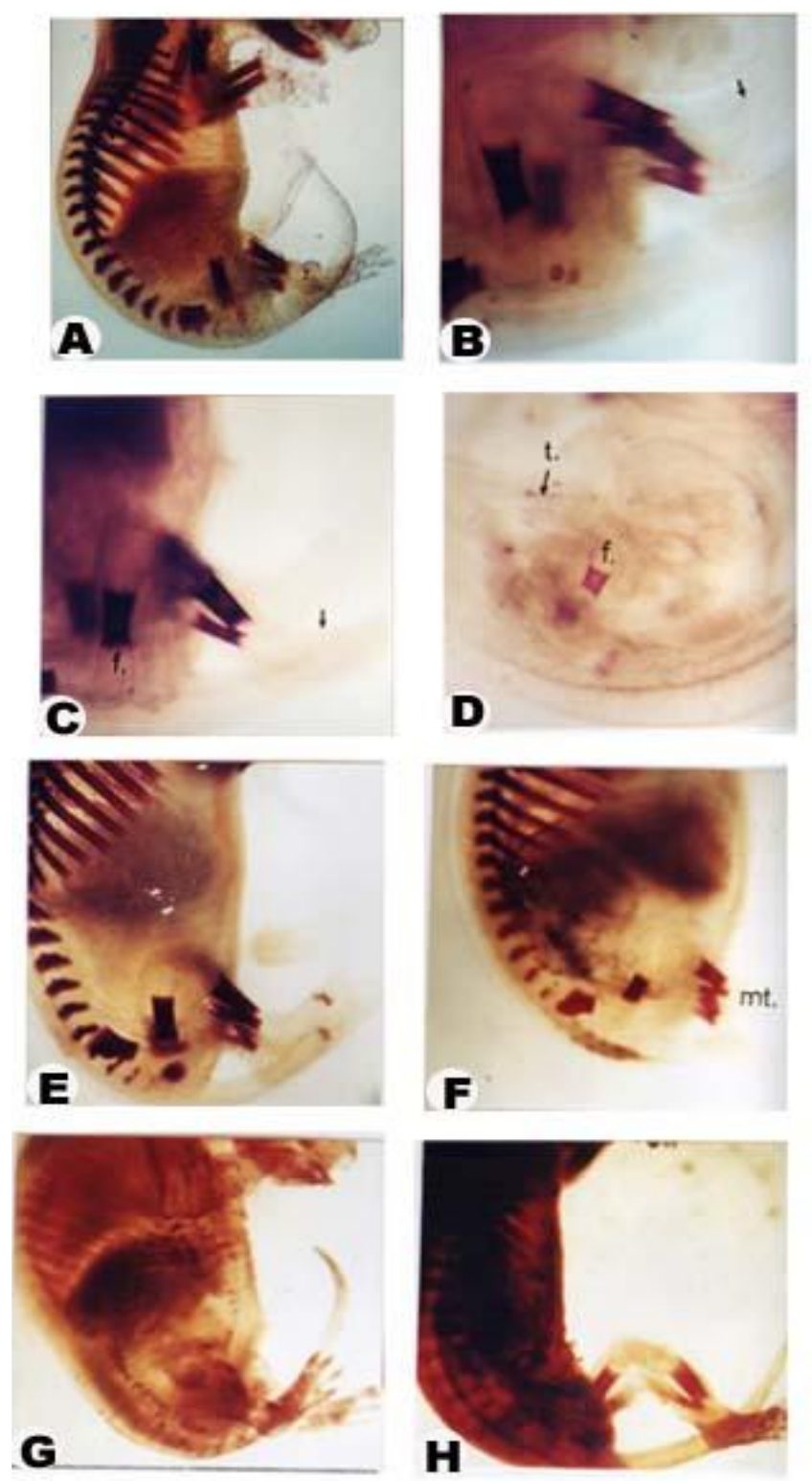

Plate (6)

Plate (5): A \& E - Photomicrograph of control mouse both $15^{\text {th }}$ and $19^{\text {th }}$ day of gestation respectively, showing normal ossification of ribs and vertebral centra. B,C,D, F,G \& $\mathrm{H}$-Treated mouse embryos at both $15^{\text {th }} \& 19^{\text {th }}$ days showing missing of (c.v.), (t.v.) cervical and thoracic vertebrae centra, (i.r.) irregular ribs as well as incomplete ossification of sacral centra (s.)

Plate (6): A \& E - Photomicrograph of control mouse both $15^{\text {th }}$ and $19^{\text {th }}$ day of gestation respectively, showing normal ossification of hind limbs. B,C,D, F,G \& $\mathrm{H}$-Treated mouse embryos at both $15^{\text {th }} \& 19^{\text {th }}$ days showing incomplete ossification of hind limbs, metatarsus (mt.), loosing of metatarsus (arrow) and incomplete ossification of femur (f.). 


\section{Skeletal malformations}

Fluoxetine $\mathrm{HCl}$ doses induced various skeletal malformations after oral administration of the therapeutic doses from $6^{\text {th }}$ day up to both $15^{\text {th }}$ and $19^{\text {th }}$ days of gestation. These aberrations were manifested in incomplete ossification of skull bones, ribs abnormalities, which included irregular shape ribs, missed ribs and incomplete ossification as represented in table (2) and Plates (3-6). On the other hand, abnormalities in both vertebrae and vertebral central were manifested in incomplete ossification, missed central discs, delayed ossification as well as scoliosis of vertebral column. Also cervical and some thoracic vertebrae were missed in some fetuses as shown in plates $(3 \& 5)$. However, ossification of fore limbs showed incomplete ossification in humorous and radio- ulna. Metacarpals, proximal and distal phalanges were completely absent in some groups as in plates $(3,4 \& 6)$. Also, bones of hind limbs showed incomplete ossification in femur, tibio-fibula and metatarsal. Moreover, all bones of the treated foetuses showed retardation in their length and size when compared with those of control foetuses as shown in plate (6).

\section{Discussion}

Antidepressant drugs especially selective serotonin reuptake inhibitors (SSRI) now rank as the most frequently prescribed drugs in medicine. These drugs not only used for the treatment of major and minor depression but also for the relief of nausea and vomiting appeared in pregnant women during early pregnancy. Many articles have been published concerning the effect of psychotropic drugs on the foetuses as well as pregnant mothers (Ali, 1981; El-Nahass et al., 1983; El-Nahass, 1988; Byrd \& Markham, 1994 and Abo El-Magd, 1996). The present work aimed to study the effect of the therapeutic doses of Fluoxetine $\mathrm{HCl}$ on the pregnant mice and their progeny.

As a maternal syndrome, Fluoxetine $\mathrm{HCl}$ treatment by oral administration was shown to reflect its action on some of the pregnant female mice during the treatment. As a psychoactive drug, Fluoxetine $\mathrm{HCl}$ causes various behavioral changes at therapeutic doses, including dizziness, nervousness, twitching of head, agitation, hizzy movement as well as reduction of food intake. These findings were supported with many authors (Bremner,1984; Cohn \& Wilcox, 1985; Benfield et al., 1986; Schotzberg et al., 1987; Werincke et al.. 1988; Montgomery et al., 1989 and Borys et al., 990). Moreover, rash, urticaria and facial oedema appeared in-patient treated with Fluoxetine $\mathrm{HCl}$ by (Gorman et al., 1987) and (Moore \& Rodriguez, 1990). These behavioral changes resulted as following: Fluoxetine $\mathrm{HCl}$ perform its main action by blocking the reuptake of the neurotransmitter serotonine into presynaptic neurons, which leads to accumulation of the neurotransmitter serotonine in the central nervous system (C.N.S.), and this resulted in serotonine syndrome (Browning, 1990 and Perse et al., 1991). However, this syndrom appears to be resulted from excessive serotonergic activity in the (C.N.S.), probably mediated by activation of serotonine 5-HT (5-hydroxytryptomin) receptors (Sporer, 1995). Serotonine syndrome is characterized by mental status, behavioral changes altered muscletone or neuromuscular activity, agitation and diarrhea (Nierenberg \& Sempreban, 1993). Other symptoms associated with serotonine syndrome have included restlessness, irritability, aggressive behavior, dizziness and anxiety (Reynolds, 1995).

In the present study, the effect of the therapeutic doses of Fluoxetine $\mathrm{HCl}$ on the body weight of the pregnant female mice showed marked decrease in all treated groups when compared with the corresponding control. These reductions in the body weights were dose dependent. These previous findings were in accordance with the results of many investigators (Wuttman \& Wuttman, 1977; Ferguson, 1986; Ferguson \& Feighner, 1987; Kinney-Parker et al., 1989; Lawton et al., 1995; Altemus et al., 1996 and Curzan et al.,1997) they reported reduction in the body weight during Fluoxetine $\mathrm{HCl}$ therapy. Also, Heisler et al. (1997 \& 1999). They reported reduction in the body weight of both males and female rats after treatment with Fluoxetine $\mathrm{HCl}$ 
due to decreases of fat and protein intakes. Moreover, Dryden et al. (1996) reported and explained how and why can Fluoxetine $\mathrm{HCl}$ causes decrease in the body weight? They suggest that: serotonine and neuropeptide Y neurons in the hypothalamus, respectively inhibit and stimulate food intake. Fluoxetine $\mathrm{HCl}$ not only inhibits various aspects of the activity of the neuropeptide Yergic arcuato-paraventricular neurons but also, reduce neuropeptide $\mathrm{Y}$ release in the paraventricular nucleus, a major site of neuropeptide $\mathrm{Y}$ release which, is highly sensitive to appetite stimulating actions of neuropeptide Y. They also, suggested that serotonine may influence food intake and energy balance by inhibiting arcuato-paroventricular projection, and that the two neurotransmitters (serotonine and neuropeptide Y) may act together to regulate feeding and energy homeostasis. The reduction in the body weight in this study may be due to one of the pervious reasons, which is confirmed by Curzan et al. (1997) they also, reported the interaction between Fluoxetine $\mathrm{HCl}$ and neuropeptide $\mathrm{Y}$ in the hypothalamus.

Both phenomena of uterine contraction and dismorphology of uterine horns were induced by Fluoxetine $\mathrm{HCl}$ in all treated experimental groups when compared with the corresponding control. These findings were also observed by Ali, 1981 and El-Nahass, 1988 who used antidepressant drugs namely Motival, Ludiomil and Imitriptyline $\mathrm{HCl}$ during embryonic development in the rats, and Abo El-Magd (1996) who used Tranxene and Lexotanil (tranquilizers) with pregnant rats.The previous phenomenae may be resulted from one of the following results, the first one may be due to the ability of Fluoxetine $\mathrm{HCl}$, as a psychoactive drug, to blockage of 5HT reuptake in the smooth muscles of the myometerium layer in the uteri from the treated mothers. The second reason reported by Ficicioglu et al. (1995) who states that, Fluoxetine $\mathrm{HCl}$ induced hyperprolactinemia in female rats, and the high concentration of serum prolactine level may causes degeneration of myometrial cells that resulted in myometrial invasion by endometrial stroma. This invasion eventually progress to adenomyosis.

In the present study, oral administration of therapeutic doses of Fluoxetine $\mathrm{HCl}$ to the pregnant mice induced various teratogenic pictures in mouse embryos. These pictures were statistically significant when compared with the control ones. These pictures were manifested in reduction of foetal body weight, reduction in crownrump length, still live embryos, delaying of implantation, intrauterine death as well as resorption of embryos. The embryotoxicity effect was dose dependent. It can be said that, the previous prevailing phenomenae of teratogenicity may attributed to toxicity of Fluoxetine $\mathrm{HCl}$ due to accumulation of this drug in certain organs, placental barriers, endometrial layer of uteri as well as placental dysfunction. Similar results were recorded by many authors using Fluoxetine $\mathrm{HCl}$ as Stanford \& Patton (1993) who used pregnant rats and resulted in subcutaneous hematoma of neonates. Also, Vorhees et al. (1994), Vendittelli et al. (1995), Chambers et al. (1996) and Blayac et al. (1997) reported several prenatal and postnatal problems when the pregnant subjects treated with Fluoxetine $\mathrm{HCl}$.

David et al. (1998) and Lanczik et al. (1998) reported that, the use of Psychotropic drugs during pregnancy may cause three complications:1- Teratogenicity, 2- prenatal syndromes (neonatal toxicity), and 3- postnatal behavioral squalae behavioral toxicity. They also added, the exposure to certain psychotropic drugs in utero may increase the risk for some specific congenital anomalies, and the intrauterine exposure to the Psychotropic drugs during the second and third trimester can lead to postnatal complications; for example, floppy-infant syndrome induced after administration of Benzodiazepines (Tranquilizers) to pregnant dams. Moreover, Isenberg (1990) proved the postnatal complication following Fluoxetine $\mathrm{HCl}$ therapy during pregnancy in human being. In contradictory to the present findings, Sommi et al., 1987; Goldstein, 1990; Pastuszak et al., 1993; Koren et al., 1994; David et al., 1997 and Nulman et al., 
1997 reported that, no teratogenic effects resulted from Fluoxetine $\mathrm{HCl}$ have been observed in vivo. On the other hand, both Shuey et al. (1992) and Sadler et al. (1993) proved the teratoge-nicity of Fluoxetine $\mathrm{HCl}$ in vitro, and stated that the developmental defects that resulted from exposure of mouse embryos in whole embryo culture to Fluoxetine $\mathrm{HCl}$ induced craniofacial malformation consistent with direct action at 5HT uptake sites. Such developmental defects may produced from inhibition of 5HT uptake during the embryogenesis by interference with serotonergic regulation of growing epithelial mesenchymal embryonic cells.

Also, Shader (1992) examined two groups of women (totaling 133) who were during pregnance exposed to Fluoxetine $\mathrm{HCl}$ and documented that 3 of 44 pregnancies resulted in major abnormalities at birth. The present findings are in parallel with these results from Haloperidol (Tranquilizer) treated experimental animals. Haloperidal administrated to rats and mice after mating resulted in delay implantation of $50 \%$ of exposed animals from $2^{\text {nd }}$ to $8^{\text {th }}$ day of gestation (Tuchmann-Duplessis \& Mercier-Parot, 1971). In higher doses, Haloperidol can increase resorption in the pregnant rats and induce cleft palate in mice (Vichi, 1969). Increased rates of embryonic death and malformation have been observed among the offspring of hamsters treated with Haloperidol during pregnancy (Gill et al., 1982). Also, reduction in the foetal body weight was recorded in foetuses obtained from treated mothers with Haloperidol during pregnancy (Holson et al., 1994).

Convening to the reduction in body weight of foetuses due to treatment with Fluoxetine $\mathrm{HCl}$ the results were statistically highly significant in comparison with the control ones. These findings were confirmed by the results of Foritz et al. (1976) and El-Nahass et al. (1983). Also, crownrump of foetuses showed great reductions in Fluoxetine $\mathrm{HCl}$ treated groups, these reductions were statistically highly signifycant when compared with the control. These findings were in harmony with that of Ali (1981), El-Nahass (1988) and Abo
El-Magd (1996) who used Psychotropic drugs as Motival and Ludiomil by the first author and Amitriptyline $\mathrm{HCl}$ by the second author as antidepressant drugs while, the last author was used both Tranxene and Lexotanil as a tranquilizers. It could be suggested that: during the early embryonic development, the blastocytes lies free in the uterus, it absorbs nutrients from the surrounding fluid, which have high glycogen content. After implantation, the embryo utilizes special fluid, the embryotroph, which is mixture of uterine fluids, destroyed epithelial cells as well as blood cells (Tuchmann-Duplesis, 1975). The intrauterine development of the embryo is highly dependent on the food of mother (Giroud, $1970 \&$ 1973). The present result showed that; the level of food intake by treated mothers was severely induced. Hence, the nutrients reached to the embryo via placenta was decreased. It was also noticed that during the embryonic development, a lack or an excess of a specific nutrient, result in sever impairment of pregnancy, including embryonic death and congenital malformation. Similar results were reported by various investigators (Fichter,1993 ; Fung \& Ferrill, 2001 ; Mitchell et al.,2001; Sharma, 2001).

During the foetal stage that characterized by an intense general growth, a specific nutritional deficiency will result in growth inhibition. This inhibition was recorded by Heisler et al. (1997 \& 1999) who proved that Fluoxetine $\mathrm{HCl}$ decreases fat and protein intake but not carbohydrates intake in both male and female rats. The inhibition or retardation of the growth In the present study may be resulted to one or more of the previous reasons.

Malformation of foetuses considered a major part of the results of the present work. Oral administration of the therapeutic doses of Fluoxetine $\mathrm{HCl}$ to pregnant female mice from $6^{\text {th }}$ day up to $15^{\text {th }}$ and $19^{\text {th }}$ days of gestation induced several foetal malformations. These malformations represented by subcutaneous hematoma, which appeared in all foetuses obtained from all treated mice as well as thin skin and diminution of size. Also, exencephally was recorded in GIII and GIV which, treated orally from 
gestation $6^{\text {th }}$ day up to $15^{\text {th }}$ day of gestation by $0.104 \mathrm{mg}$ Fluoxetine $\mathrm{HCl}$. Shortness of tail, microcephally, scoliosis as well as oedematous ascites were observed. These results were similar to those described by Ali (1981), Sanyal \& El-Nahass (1983) and James et al. (1986), who worked on antidepressant drugs as Motival, Ludiomil and Imipiramin, respectively. Also, these findings were in accordance with Ibraheem et al. (1998) when found teratogenic effect of Nefopam $\mathrm{HCl}$ (sedative drug) on the embryonic development of the rats.

Skeletal defects of foetuses obtained from Fluoxetine $\mathrm{HCl}$ treated mothers that were sacrificed on $15^{\text {th }}$ day and $19^{\text {th }}$ day of gestation have been observed. These defects included incomplete ossification of most skull bones, irregular and missed ribs, absence of vertebral centra and scoliosis as well as incomplete ossification of both fore and hind limbs. The major skeletal defects were skull anomalies, including non ossification centers of several skull bones maxilla, nasal, parital, interparital, supraoceipital and basioccipital. The percentages of these defects were dose dependent.

Ali (1981) reported similar result using antidepressant drugs namely Motival and Ludiomil. Also, these results confirmed by those of McColl et al, (1963) and Dwornik \& Moore (1965) When described a delay or incomplete ossification of skull and sternum of rat foetuses treated with Thalidomide (Tranquilizer). Moreover, Dipaolo (1963) and Dipaolo et al. (1964) reported that, Thalidomide administrated to mice caused sever spinal abnormalities. The deficient growth of the base of the skull specially that of basioccipital has been considered to be caused by primary mesodermal insufficiency (Marin-Padilla, 1966). Also, injury to the paraxial mesoderm during early embryonic development (organogenesis) could result in a primary mesodermal in sufficiency which in itself, may be cause a variety of developmental abnormalities involving the various axial structures. This findings also, were quite confirmed by El-Nahass et al. (1983) who reported that the use of Fluphenazine $\mathrm{HCl}$ during pregnancy induced absence of $5^{\text {th }}$ centrum in rat foetuses and delayed or induced incomplete ossification of the sternum and vertebral column. Also, the present findings are in agreement with those obtained by Rumea-Roquette et al. (1977) who reported that Fluphenazine $\mathrm{HCl}$ (Tranquilizer) caused inhibition or delayed the ossification in vertebrae, ribs and scoliosis in vertebral column in human foetuses.

In the present study, there was no ossification especially metacarpals and metatarsals except in some individual foetuses in GVII when compared with normal ones and these also were dose dependent. These results in agreement with those reported by Ali (1981), El-Nahass (1988) and Abo El-Magd (1996). It may suggested that malformations of foetal skeletal system attributed to the decreased absorption rate of calcium from the intestine and/or injuries induced in the liver of female pregnant rats previously treated by Chlorpromazine (Othman et al., 1981). Liver hepatitis was found to be decrease the formation of vitamin $\mathrm{D}$ metabolite (monohydroxy vitamin D) which in renal tissues will be rehydroxylated (1, 25 dihydroxy vitamin D) forming active principle metabolite responsible for calcium absorption from intestine. The present findings supported by Azmitia et al. (1990) who studied the effects of 3,4-methylene dioxymethamphetamine (MDMA) on cultured serotonergic neurons of foetal raph neurons of rats to evidence for $\mathrm{Ca}^{2+}$ dependent toxicity linked. They found that 5-HT (5-hydroxytryptamine) receptor is linked to increased intracellular $\mathrm{Ca}^{2+}$, this linkage inhibited Fluoxetine $\mathrm{HCl}$ action.

Also, Moiseiwitsch et al. (1998) reported that, serotonine (5-HT) and its serotonergic ligands (which blocked by Fluoxetine $\mathrm{HCl}$ ) regulate the calcium binding protein and tenascin (extracellular matrix molecule) which, together are important in cranio-facial development, and cartilage proteogylcan core protein. This regulation is stimulated by serotonine (5HT) in tooth-germ development in embryonic mouse mandibular explant in cultures, which inhibited by Fluoxetine $\mathrm{HCl}$. The present study suggested that the oral administration of Fluoxetine $\mathrm{HCl}$ to the 
pregnant mice induced delaying of the ossification and sever skeletal anomalies which may be due to mesenchymal condensation during embryonic development, or may be due to resorption of cartilage, during embryonic development, which precedes endochondral ossification, which adversely affected by Fluoxetine $\mathrm{HCl}$ doses. These results were also confirmed by Cancholal - Martinez et al. (1997) they reported that certain Psychotropic drugs inhibits calcium-calmodulin-system in rat neonates as a systemic action of these Psychotropic drugs(Verapamal, Haloperidol and Penfluridal). The present work suggested that Fluoxetine $\mathrm{HCl}$ either inhibits $\mathrm{Ca}^{+2}$ metabolism in both extrac-ellular and intracellular matrix molecule or caused blocking of serotonergic ligands that regulate calcium binding protein and this may be lead to the inhibition of serotonin 5HT receptor gene or to response of certain genetic factors to interacting with the antidepressent drug (Fluoxtine). These suggestion were supported by many authors (Moiseiwitsch ,2000).The former one reported that the prozac and less selective tricyclic antideperessant drug like Elavil would be at a higher risk for developmental dental defects such as anodontia \& hypodontia and will cause major cranioficial malformation. While Okada reported that A human serotonin $(5-\mathrm{HT})(2 \mathrm{C})$ receptor gene polymorphism leads to the substitution of cysteine for serine at codon 23 (Cys23Ser); the frequency of the Ser23 allele in unrelated Caucasians is approximately 0.13 . Although the amplitude of the 5 HT-induced intracellular $\mathrm{Ca}(2+)$ peak did not differ between the alleles, Ser23 required higher 5-HT concentrations to elicit the same response. These results indicate that the Ser23 allele may be constitutively more active than Cys23. Thus, Ser23 appears to be an abundant candidate allele capable of directly influencing inter-individual variation in behavior, susceptibility to mental disorder, and response to drugs including atypical antipsychotic and some antidepressant drugs that are potent 5 -HT(2C) inverse agonists or antagonists.

Eventialy, the present work awarance the medical community and drug manufac- turers that it should make a concerted effort to protect women and their unborn babies from risk associated with fetal exposure to teratogenic drugs, which can lead to unneccessary abortions.

\section{References}

1. Abo El-Magd, M.H. (1996): Possible Teratogenicity and mutagenicity induced by some Benzodiazepines in rat embryos Ph.D. Thesis. Fac. Sci. Al-Azhar Univ.

2. Ali, M.O. (1981): Studies on some embryological aspects induced by certain antidepressant drugs in mammalian embryos. Ph.D. Thesis, Fac. Sci., Al-Azhar Univ.

3. Ali, M.O.; El Nahass, E.; Diamond, M.O. and Desouki, G. (1989): Embryotoxic effect of Diabetes mellitus. Al-Azhar Medical J. 17(4): 421-428.

4. Altemus, M.; Glowa, J.R.; Galliven, E.; Leong, Y.M. and Murphy, D.L.(1996): Effects of Serotonergic agent on food restriction induced hyperactivity. PharmacolBiochem. - Behav, 53(1): 123-131.

5. Azmitia, E.C.; Murphy, R.B. and Whitaker- Azmitia, P.M. (1990): MDMA (ecstasy) effects on culture serotonergic neurons: evidence for $\mathrm{Ca}^{2+}$ dependent toxicity linked to release. Brain Res. 510(1): 97-103.

6. Barlow, M.S.; Knight, A. F. and Sullivan, F.M. (1980): Diazepam- induced Cleft palate in the Mouse: The Role of Endogenous Maternal Corticosterone. Teratology, 21: 149-155.

7. Benfield, P.; Heel, R.C. and Lewis, S.P. (1986): Fluoxetine: a review of its pharmacodynamic and pharmacokinetic properties, and therapeutic efficacy in depressive illness. Drug. 32:481-508.

8. Blayac, J.P.; Hillaire - Buys, D. and Peyriere, H. (1997): Pharmacovigilance of new antidepressants: evaluation of neuropsychobehavioral disorders. Therapie, 52(2): 117-122.

9. Borys, D.J.; Setzer, S.C. and Ling, L.J. (1990): Acute Fluoxetine overdose: a report of 234 cases. Am. J. Emerg. Med.; 10:115120.

10. Bremner, J.D. (1984): Fluoxetine in depressed patients: a comparison with imipramine. J. Clin Psychiatry 45:414-419.

11. Browning, W.N. (1990): Exacerbation of symptoms of multiple scerosis in a patient taking Fluoxetine (Letter). Am J. Psychiatry. 147:1089. 
12. Byrd, A.R. and Markham, J.K. (1994): Developmental toxicology studies of Fluoxetine $\mathrm{HCl}$ administrated orally to rats and rabbits. Fundam. Appl. Toxicol., 22 (4): 511-518.

13. Canchola - Martinez, E.; Vergara Onofre, M.; Rodriguez - Medina, M.A. and Mercado - Sanchez, G. (1997): Inhibitors of calcium - calmodulin system and hypothalamic sex differentiation in rats. Biochemical parameters. Ginecol - Obstet Mex. 65:508-514.

14. Chambers, C.D.; Johnson, K.A. and Dick, L.M. (1996): Birth outcome in pregnant women taking Fluoxetine. N. Engl. J. Med. 335:1010-1015.

15. Cohn, J.B. and Wilcox, C. (1985): Comparison of Fluoxetine, Imipramine and Placebo in patients with major depressive disorder. J. Clin Psychiatry, 46 : 26-31.

16. Cook, M. and Farweather, F. (1968): Methods used in teratogenic testing Lab. Anim. 2:219-228.

17. Curzan, G.; Gibson, E.L. and Oluyomi, A.O. (1997): Appetite suppression by commonly used drugs depends on 5-HT receptors but not on 5-HT availability. Trends - Pharmacol. Sci. 18(1):21-25.

18. David, J.; Lois, A.; Goldstein, R.N.; Corbin, R.N. and Sundell, L.K. (1997): Effect of first trimester Fluoxetine exposure on the newborn. Obsetetrics and Gynecology. 89(5) 1:713-718.

19. Dipaolo, J.A. (1963): Congenital malformation in strain A mice. J.A.M.A. 183: 139-141.

20. Dipaolo, J.A.; Gatzek, H. and Picken, J. (1964): Malformations induced in mouse by thalidomide. Ama. Rec. 149:149-156.

21. Dryden, S.; Frankish, H.M.; Wang, Q.; Pickavance, L. and Williams, G. (1996): The serotonergic agent Fluoxetine reduces neuropeptide Y levels and neuropeptide Y secretion in the hypothalamus of lean and obese rats. Neurosciance. 72(2):557-566.

22. Dwornik, J.J. and Moore, K.L. (1965): Skeletal malformations in the Holtzman rat embryo following the administration of thalidomide. J. Embryol. Exp. Morphal. 13:181.

23. El-Nahass, A.M. (1988): Effect of certain Psychotropic drugs on pregnant rats and their offspring's. Ms.D. Thesis, Fac. Sci. Al-Azhar Univ.

24. El-Nahass, S.M.; Ali, M.O. and ElNahass, E. (1983): Congenital abnormallities in rat embryos associated with maternal use of fluphenazine $\mathrm{HCl}$ during pregnancy. Egypt, J. Genet. Cytol. 12:449458.

25. Ferguson, J.M. (1986): Fluoxetine induced weight loss in over weight, nondepressed subjects. Am. J. Psychiatry, 143:1496 (Letter).

26. Ferguson, J.M. and Feighner, J.P. (1987): Fluoxetine induced weight loss in over weight non-depressed humans. Int. J. Obese. 11(3):163-170.

27. Fichter , M.M.(1993): Drug treatment of anorexia nervosa and bulimia nervosa. A review. Nervenarzt. 64(1):21 - 35 .

28. Ficicioglu, C.; Tekin, H.I.; Arioglu, P.F. and Okar, I. (1995): A murine model of adenomyosis: the effect of hyperprolactinemia induced by Fluoxetine $\mathrm{HCl}$, a selective serotonin reputake inhibitor, on adenomyosis in induction in Wister albino rats. Acta. Eur. Fertil. 26(2): 75-79.

29. Foritz, H.D.; Mudler and Hess, R. (1976): Comparative study of teratogenicity of Phenobarbitone, Diphenylydantation and Carbamazepine in mice. Toxicology. 6(3): 323-330.

30. Fung, S.M. and Ferrill, M.J.( 2001): Treatment of bulimia nervosa with ondansetron. Ann Pharmacother. 35(10): 1270-3.

31. Giroud, A. (1970): The nutrition of the embryo. Thomas, Spring Field : 10-51.

32. Giroud, A. (1973): Nutritional requirements of the embryo. World review of nutrition and dietetics, 18:195-196.

33. Globus, M. and Gibson, M.A. (1968): A histological study of the development of the sternum in thalidomide treated rats. Teratology. 1: 235-256.

34. Goldberg, H.L. and Nissim, R. (1994): Psychotropic drugs in pregnancy and lactation. Int. J. Psychiatry Med. 24 (2):129-147.

35. Goldstein, D.J. (1990): Outcome of Fluoxetine exposed pregnancies. Am. J. Hum. Genet. 47: A136.

36. Gorman, J.M.; Liebowitz, M.R. and Fyer, A.J. (1987): An open trial of Fluoxetine in the treatment of panic attacks. J.Clin. Psychopharmacal. 7:329-332.

37. Heisler, L.K.; Kanare K.R.B. and Gerstein, A. (1997): Fluoxetine decreases Fat and protein intakes but not carbohydrate intake in male rats. Pharmacal. Biochem. Behav. 58(3): 676-773.

38. Heisler, L.K.; Kanare K.R.B. and Gerstein, A. (1999): Reduction of fat and protein intakes but not carbohydrate intake 
following acute and chronic administration of Fluoxetine in female rats. Pharmacal. Biochem. Behav. 63 (3) : $377-385$.

39. Holson, R.R.; Webb, P.J.; Grafton, T.F. and Hansen, D.K. (1994): Prenatal neuroleptic exposure and growth stunting in the rat: an in vivo and vitro examination of sensitive periods and possible mechanisms. Teratology. 50 (2): 125-136.

40. Ibraheem, M.A.; Zaki, T.Z. and Nadia, H.I. (1998): Tertagoenic and histopathological effect of Nefopam $\mathrm{HCl}$ on rat foetuses. J. Egypt. Ger. Soc. Zool. 25 (B), 185-239.

41. Isenberg, K.E. (1990): Excretion of Fluoxetine in human breast milk. J. Clin. Psychiatry. 51:169 (Letter).

42. James, R.; Harmon, Peggy, J.; Webb; Gary, L.; Kimmel and Robert, R. (1986): Effect of prenatal imipramine exposure on development of the postnatal rat heart and brain. Teratogenesis, Carcinogenesis and Mutagenesis. Med. J. 18: (8) : 416-424.

43. Kaplan, S. and Grabowski, C.T. (1967): Analysis of Trypan blue-induced rumplessness in chick embryos. J. Exp. Zool. 165:325-336.

44. Kinney-Parker, J.L.; Smith, D. and Ingle S.F. (1989): Fluoxetine and weight: Some thing last and some thing gained? Clin. Pharm. 8:727-733.

45. Koren, G.; Pastuszak, A.; Jasobson, S.; Schick, B.; Donnenfeld, A.; Feldkamp, M.; Zuber, C.; M.G. Cormack, M.; Jones, K. and Gardener, H.A. (1994): The safety of antidepressants in pregnancy. Maternal fetal Toxicology. A Clincans Guide second edtion. Koren, G. ed. New York, NY-U.S.A Marcel - Dekker, Inc. 2:59-76.

46. Lanczik, M.; Knoche, M. and Fritz, J. (1998): Psychopharmacotherapy during pregnancy and lactation.1: pregnancy. Nervenarzt. 69(1): 1-9.

47. Lawton, C.L.; Wales, J.K; Hill, A. J. and Bundell, J.E. (1995): Serotonergic manipulation, meal - induced satiety and eating pattern: Effect of Fluoxetine in obese female subjects. Obese-Res. 3 (4): 345-356.

48. McColl, J.D.; Globus, M. and Robinson, S. (1963): Drug induced skeletal malformations in rat. Experintia (Basel). 19:183.

49. Mitchell, J.E.; Peterson, C.B.; Myers, T. and Wonderlich, S.(2001): Combining pharmacotherapy and psychotherapy in the treatment of patients with eating disorders.
Psychiatr. Clin. North. Am. Jun. 24(2):31523.

50. Moiseiwitsch, J.R. (2000): The role of serotonin and neurotransmitters during craniofacial development. Crit Rev Oral Biol Med. 11(2):230-9.

51. Moiseiwitsch, J.R.; Raymond, J.R.; Tamir, H. and Lauder, J.M. (1998): Regulation by serotonin of tooth-germ morphogenesis and gene expression in mouse mandibular explant cultures. Arch oral Biol. 43(10): 789 - 800 .

52. Montgomery, S.A.; Dufour, H. and Brion, S. (1989): Prophylactic efficacy of Fluoxetine in unipolar depression. Br. J. Psychiatry. 153 (3): 69-76.

53. Moore, J.L. and Rodriguez, R. (1990): Toxicity of Fluoxetine in over dose. Am. J. Psychiatry, 147:1089.

54. Nierenberg, D.W. and Sempreban, M. (1993): The central nervous system serotonin syndrom. Clin. Pharmacal Ther. 53:84-88.

55. Nulman, I.; Rovet, J.; Stewart, D.E.; Wolpin, J.; Gardner H.A.; Thesis, J.G.W.; Kulin, N. and Koren, G. (1997): Neurodevelopment of children exposed in utero to antidepressant drugs. N. Eng. J. Med. 336:258-262.

56. Othman, A.B.; El-Seddik and El-Kholy, W. (1981): Studies on calcium metabolism in chlorpromazine treated female and pregnant rats. Ain Shams Medical J. Ain Shams University Hospitals, Abbasia, Cairo.

57. Pastuszak, A.; Schick-Boschetto, B. and Zuber, C. (1993): Pregnancy outcome following first. Trimester exposure to Fluoxetine (Prozac). JAMA. 269:22462248.

58. Perse, T.; Meyers, F. and Hegyvary, C. (1991): New Pespatives on Fluoxetine (Prozac): Promixe, Problems and Potential dangers. Emerg. Med. Repots. 12:73-80.

59. Reynolds, R.D. (1995): Serotonin syndrom: what family physicians need to known. Am. Fam. Physician; 52:12631271.

60. Rumeau-Rouquette, C.; Goujard, J. and Heul, G. (1977): Possible teratogenic effect of phenothiazine in human beings. Teratology. 15:57-64.

61. Sadler, T.W.; Shuey, D.L. and Lauder, J.M. (1993): Serotonine and cardiac morphogenesis in the mouse embryo. Teratology. 47 (6) : 573-584.

62. Sanyal, M.K. and Eric, A.W. (1979): Oxygen requirement in Vitro growth and 
differentiation of the rat conceptus during organogenesis phase of embryo development. Biology of Reproduction. 20: 639- 647.

63. Schotzberg, A.F.; Dessain, E. and O`Neil, P. (1987): Recent studies on selective serotonergic antidepressants: trazodone, Fluoxetine and Fluvoxamine. J. Clin Psychopharmacal. 7:445-495.

64. Shader, R. (1992): A patient of mine missed aperiod while taking Fluoxetine; it turned out that she was not pregnant. However, the question arose about the safety of Fluoxetine during pregnancy. What is known? (Response). J. Clin. Psychopharma, 12:213.

65. Sharma, A.( 2001): Anorexia nervosa and bulimia nervosa: An appraisal. Drugs Today (Barc). 37(4):229-236.

66. Shuey, D.L.; Sadler, T.W. and Lauder, J.M. (1992): Serotonin as a regulator of Craniofacial morphogenesis: Site specific malformations following exposure to serotonin uptake inhibitors.

67. Sommi, R.W.; Crismon, M.L. and Bowden CL. (1987): Fluoxetine: a serotonin specific, second generation antidepressant. Pharmacotherapy. 7:1-15.

68. Sporer, K.A. (1995): The serotonine syndrome. Implicated drugs, Pathologysiology and management. Drug Saf. 13:94-104.

69. Stanford, M.S. and Patton, J.H. (1993): In utero exposure to Fluoxetine $\mathrm{HCl}$ increases haematoma frequency at birth.
Pharmacy. Biochem. Behav. 45(4): 459962.Teratology, 46 (4): 367-378.

70. Tuchmann-Duplesis, H. (1975): Durg effects on the Foetus. ADIS. Press. Sydney: 15-57.

71. Tuchmann-Duplessis, H. and Mercier Parot, L. (1971): Influence of neuroleptics on prenatal development in mammals. In : Tuchmann - Duplessis, H. (Eds): Malformations, Tumors and mental Dafects, pathogenetic correlations. Carlo Erba Foundation. Milan.

72. Vendittelli, F.; Alain, J. and Nouaille, Y. (1995): A case of lipomeningocele reported with Fluoxetine (and alprazolam, vitamins B1 and B6, heptaminol) prescribed during pregnancy. Eur. J. Obstet. Gynecol. Reprod. Biol. 58:85-86.

73. Vichi, F. (1969): Neurolepic drugs in experimental teratogenesis. In Bertelli and Donati, (eds): Teratology Proceedings, Amesterdam, Excepta. Medica. : 87-101.

74. Vorhees, C.V.; Acuff-Smith, K.D. and Schilling, M.A. (1994): A developmental neurotoxicity evalution of the effects of prenatal exposure to Fluoxetine in rats. Fundam. Appl. Toxicol. 23 (2) : 194-205.

75. Wernicke, J.F.; Dunlop, S.R. and Dornseif, B.E. (1988): Fixed dose of Fluoxetine therapy for depression. Psychopharmacal. Bull. 23:164-168.

76. Wuttman, J.J. and Wuttman, R.J. (1977): Fenfluramine and Fluoxetine spare protein consumption while suppressing caloric intake by rats. Science. 198:11781180 . 
تأخر النمو الجنيني و التثوهات الهيكلية المحدث بواسطة القلوكسيتين

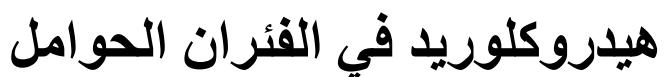

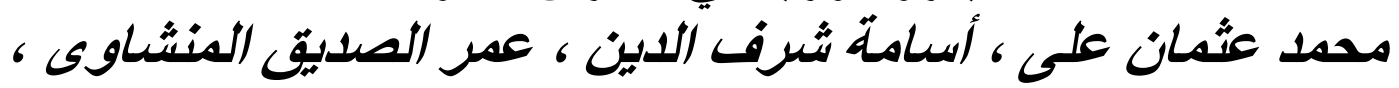

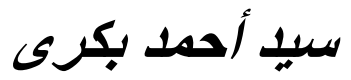

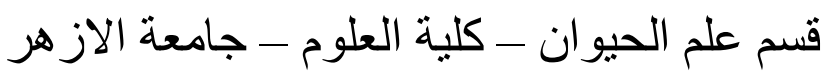

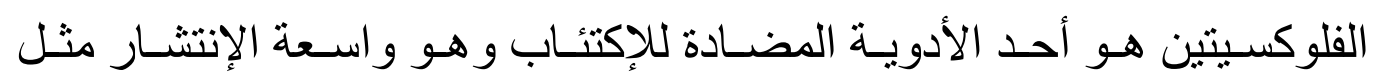

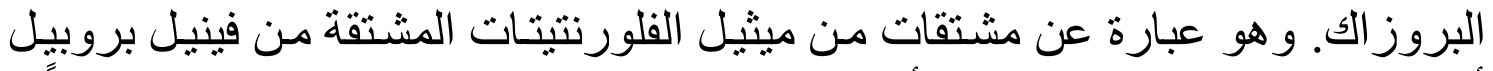

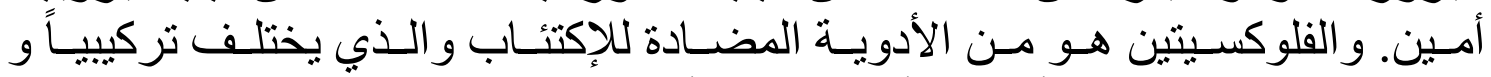

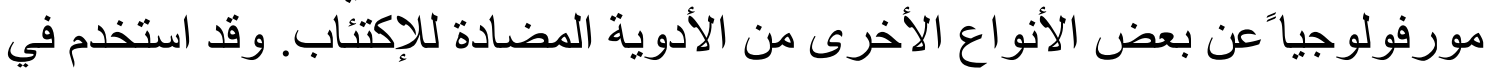

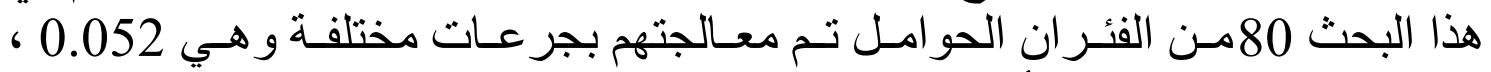

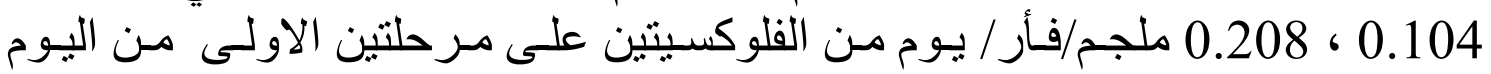

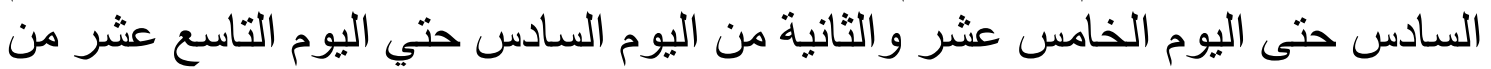

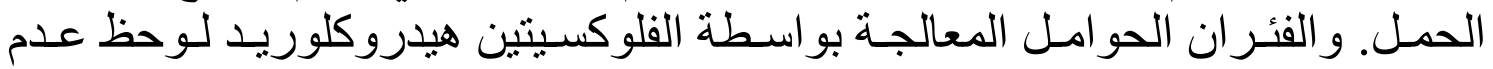

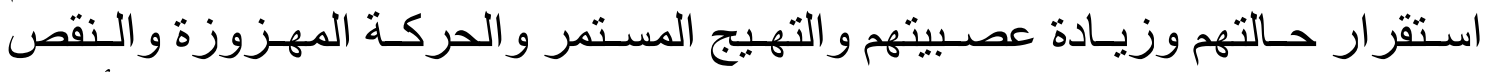

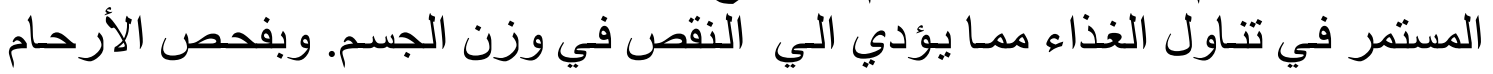

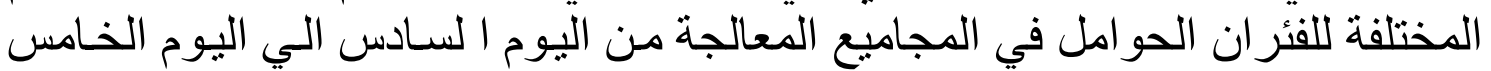

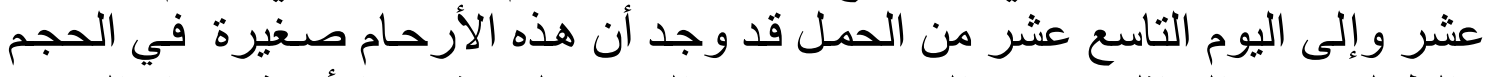

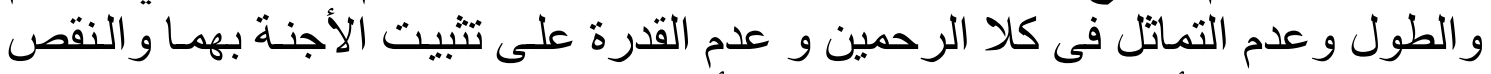

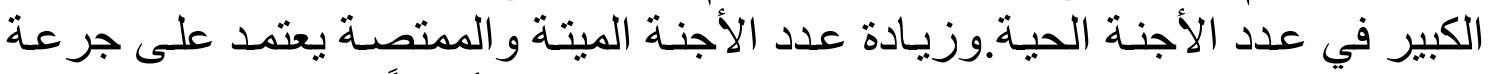

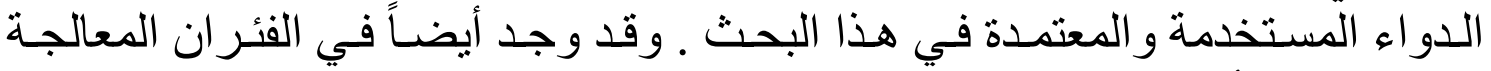

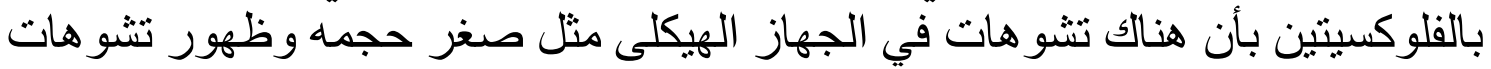
في الر اس (اكسينوسفاليا). 